\title{
Civilized Warriors? \\ Professional Disciplines, Ethos, and European Armed Forces
}

By Patrick Mileham*

\section{BEMUSED AND BEWILDERED}

"Let us be very clear," declared NATO Secretary General Lord Robertson in March 2001. "There is, and will be, no single European Army. There will be no standing European Force." He reassured the audience, "National armed forces will remain just that; national forces under the command of national governments."

While he was articulating a NATO position on the development of European armed forces, Robertson might have been distancing NATO, deliberately or subconsciously, from the European Union's (EU) concept of the development of many of those same national armed forces, which could lead to a single EU Army, Navy and Air Force, in perhaps ten or twenty years' time. Indeed, the EU generally, and particularly the "Old European" national leaders, are zealously driving forward the Common Foreign and Security Policy (CFSP), the European Security and Defense Policy (ESDP) and - whatever it means - a European Security and Defense Identity (ESDI). ${ }^{2}$ Are the decision-makers merely ideologists, whose successors in office will preside over bemused, bewildered, and less than competent warriors, or are they truly finding a way towards comprehensible, comprehensive, and effective security arrangements for the greater peace and stability of the world? Indeed, one should probably look even farther afield, to the forty-four nations that come together in the EuroAtlantic Partnerships Council (EAPC), spread geographically from North America to the Urals, in promoting military professionalism as an integral factor of developing international stability.

The aim of this article is to explore certain qualitative principles, competencies, and criteria as means of professionalizing the armed forces of Europe, building internal and international confidence, and thereby assisting in the extension of democracy and security. ${ }^{3}$ The term "disciplines" is used inten-

\footnotetext{
* Dr Patrick Mileham is at the Business School, University of Paisley, Scotland, specialising in ethics and morale in armed forces. He is a noted author on post-cold war European militaries.

${ }^{1}$ Lord Robertson of Port Ellen, "NATO - The Enduring Mission," RUSI Journal 146:2 (April 2001): 5.

2 "Old Europe," a dismissive term used by U.S. Secretary of Defense Donald Rumsfeld, particularly in response to French, German, and Belgian resistance to the proposed military action against Iraq, quoted in the Financial Times, 18 February 2003.

${ }^{3}$ This article is the basis for a future research project proposed by the author. Some of its themes have already been revealed in a book chapter, "Professional Armed Forces: Concepts and Practices," in Defence Management in Uncertain Times, ed. Teri McConville and Richard Holmes (London: Frank Cass, 2003).
} 
tionally, suggesting a convergence of the practical and the intellectual, while also implying a search for a universal doctrine of the military profession.

The genesis of this study was a request made to the author in 2001 by the NATO Secretary General's Special Advisor for Eastern Europe, Christopher Donnelly, to define what actually constitutes military competence, and to flesh out a description of what is meant by "professional armed forces." No proper definition of theory and practice existed at that point. ${ }^{4}$

Much of the literature and work on professionalizing armed forces has been concerned with post-Cold War reductions of mass conscript armies of continental Europe and the former Soviet Union, and particularly the implications for internal civil-military relationships, country by country. The term "professional" has chiefly been used by analysts outside the military, as the opposite of "conscripted." This article views armed forces from the inside looking out, concentrating on professionalism as an index of the quality of military activity, its efficiency, competency, and effectiveness. It does not exclude civil-military duty as a part of the fabric of the nation, or national service in its widest context. Full-time military service, referred to as "regular" in Britain, and synonymous with professional or "contract" military service in other languages, is thus the chief focus of this study.

To start with, one has to pose the following questions of first principles:

- What are armed forces for?

- How do they work?

- What combat roles are envisaged?

- What are the restraints on "fighting"?

- Why should individuals join the armed forces as a matter of choice?

- Is the military a "true profession"?

Since international law indicates that military action should be the choice of last resort, the "management of violence"s rather than the "act itself" is a partial answer to the first question. While there is much classical theoretical literature on the subject, from writers such as Samuel Huntingdon, Jacques van Doorn, Charles Moskos, and Morris Janowitz, it will not be rehearsed here.

It is suggested that addressing these questions as both an intellectual and a practical exercise, leading to a set of disciplines, can help affirm a level

\footnotetext{
${ }^{4}$ Conference entitled "Reforming the Ukrainian Armed Forces," held in July 2001 at the Centre for Defence and Security Studies, University of Lancaster. The intention was to develop a complete rationale and universal code for military service, far more than a mere 'benchmarking' system. The sociology (rather than theory or policy) of military professionalism has been developed by M. D. Feld (ascriptive), Arthur Larson (radical/pragmatic), Charles Moskos Jr. (institutional/occupational), and Giuseppe Caforio and Marina Nuciari (hybrid models). See Giuseppe Caforio, ed., Handbook of the Sociology of the Military (New York: Kluwer Academic/Plenum Publishers, 2003), 69-70.

${ }^{5}$ Harold Lasswell, The Analysis of Political Behaviour (London: Kegan Paul, 1947), 152.

${ }^{6}$ Samuel P Huntington, The Soldier and the State (Cambridge, MA: Belknap Press of Harvard University Press, 1957), 13.
} 
of professional confidence among members of armed forces, civilian leaders, and national populations generally. The ultimate purpose of articulating professional military disciplines is to promote peace.

\section{Evaluating Competent Armed Forces}

A general description of the military profession cites three components of "military effectiveness" and "fighting power": Conceptual, Moral, and Physical.7 With particular regard to the latter, the military capabilities of all national armed forces are measured annually by such bodies as the International Institute for Strategic Studies (IISS) in The Military Balance, together with the Stockholm International Peace Research Institute (SIPRI) in their Yearbook. The Royal United Services Institute for Defence Studies (RUSI) also produces annually the "Index of Martial Potency," which compares and contrasts the military resources of nations by region and globally. But these quantitative studies tell only half the story. In the rubric to the "Index," the RUSI editor, Michael Codner, warns that:

It does not take account of a nation's efficiency in using defence resources, nor of such crucial issues as morale nor of the types of capability that are maintained.... A wider measure of national power would be required which would include all the sources of national power and weakness. ${ }^{8}$

It is the quality of the national armed forces in relation to "all sources of national power and weakness" that ought to concern politicians, military leaders, and those members of their publics who are serious about international defense and security.

It must be stated that a number of liberal democracies are extremely sensitive about the "function" of their military institutions. Some view their place in the nation as little short of ideologically embarrassing, and look at them as something of a necessary evil. The indications are that they do not wish their armed forces to be efficient; professionalism is perhaps directly or subconsciously equated with militarism, the enemy of civil society. Others accept armed forces as nation-building institutions, in default of other manifestations of national service or identity. In his introduction to his 2002 book Democracy and Military Force, Philip Everts juxtaposes the "traditional restraining role ... of public opinion... when democracies have to decide on war and peace" and the "dangers of letting public opinion take charge of matters that are better left

\footnotetext{
${ }^{7}$ Ministry of Defence, British Defence Doctrine, (Second Edition) JWP 0 - 01, 2001 (first edition 1996), prescribed "bases," rather than "components," citing five: Conceptual, Moral, Personnel, Material, and Supporting Infrastructure.

${ }^{8}$ Michael Codner, “The RUSI Martial Potency Index 2002,” RUSI Journal 147:6 (December 2002): $14-15$.
} 
in the hands of trusted experts." ${ }^{\prime 9}$ The conscripted service tradition restrains the development of fully objective military competence. Some liberal democracies - where the experts have indeed been well trusted - have mounted successful offensive military operations to compel and coerce errant nations and groups with the use of actual force, or to deter wrongdoing, such as in peacekeeping and humanitarian tasks. A nation's seriousness about military intent is usually related to GDP, although the military output or return on investment for the less robust and conscript-bound nations must be increasingly unsatisfactory. Conscription is expensive. It is also universally unpopular.

Some nations are therefore comfortable and "at one" with their armed forces, while others have maintained them with much less enthusiasm, prompted by different national political agendas and with reciprocal social distance and unpopularity. In the past two years it has become apparent that there is a growing, if not acute, need for an international reviewing of the level of professionalism of armed forces if they are to play an effective part in providing and maintaining security in the future. Specific military and more general security threats seem set to become even more diverse in character and of greater magnitude since September 11, 2001 than in the previous decade; they are likely to become even more dangerous, unpredictable, and sudden.

\section{Peace Dividend}

Many of the factors and consequences likely to affect the security and insecurity of the world, most notably in European and adjacent nations, were barely recognized in the years following the fall of the Berlin Wall in 1989 and the end of the Cold War. That event occurred because "Gorbachev's peace offensive ... [had] desperately sought to wind down an arms race with the technologically superior West that would cripple Soviet economy and society." 10 The Soviet Union dominated the Warsaw Pact member-nations in a way that was different from the dominance by the United States of NATO. That is why the Warsaw Pact collapsed so quickly, while NATO did not. This is not to say NATO is not slowly unravelling, or sensibly transforming, depending on whether one's viewpoint is gloomy or confident. It is nevertheless not unreasonable to point out that, from the perspective of the only remaining superpower, militarily the armed forces of an "Old Europe" conscription-based nation appear as unprofessional as those of a former Warsaw Pact nation's army, navy, and air force. The difference is that the former are rich and mature liberal democracies, while the latter are neither. Post-Cold War NATO sometimes seems effectively to suspend disbelief, while asserting that security is just more of the same old soldierly ideas and military habits.

\footnotetext{
${ }^{9}$ Philip Everts, Democracy and Military Force (Basingstoke: Palgrave, 2002,), xi.

${ }^{10}$ Vladislav M. Zubok, "Why did the Cold War End in 1989? Explanation of "The Turn," in Reviewing the Cold War. Approaches, Interpretation, Theory, ed. Odd Arne Westad (London: Frank Cass, 2001), 349.
} 
One test of political maturity is the nature and quality of civil-military relationships, both in terms of civil control over the military and the armed forces' relationship with the population. Some nations do not see America's military as truly professional as Americans do themselves. Professionalism is much more than powerful capability. Europeans see in the U.S. a type of sub-conscious militaristic culture that has proved to be so dysfunctional in the past. ${ }^{11}$ It must also be pointed out that the much-trumpeted "revolution in military affairs" has had little material application in most of the nations of Europe. One can take little pride in the performance of most European nations' armed forces in the last decade. It is indeed difficult to see in what currency the peace dividend has been paid. That having been said, the Conference for Security and Cooperation in Europe (CSCE) Helsinki agreement of 1975 led to a series of military and diplomatic confidence building measures in the 1980s, replaced directly by admirable post-Cold War Partnership for Peace (PfP) and Defence Diplomacy initiatives. But the question has to be asked, leading to what?

It is relevant to reflect, going back to the future, on what analysts believed in previous decades. Morris Janowitz, who has done so much to promote the understanding of military sociology since the 1960s, foresaw five indicators of change in 1960: a modification of "the basis of authority and discipline" in the direction of more persuasive methods of control; that "professionalism" would make progress by producing a nearer resemblance between the military and society; career structures would change to enable promotion for competence rather than patronage; a diminishing of skill differentials would occur between military and civilian elites through embracing scientific managerial methods; and the development of an increasingly "explicit political ethos." This latter trend did not mean political interference by the military, but rather enhancing and maintaining civil control over the military by greater reciprocal awareness and maturity in military decision-making. ${ }^{12}$ Thirty years later, in 1990, Charles Moskos, Jr., another leading military sociologist of long standing, asserted that, "the active duty force would shrink dramatically to a well paid professional cadre"; "the soldier/scholar" professional would emerge "as the officer corps became a component of the general advisory service or the state on matters of international security [and]... Security studies [would become] broadly conceived ... and significantly changed from the narrow focus on war fighting." In addition, conscription for military service would diminish, and in "states that persisted with the practice" it would become less acceptable; "the military/police divide in many states" would become obscured, as "armed forces took on not only more policing type functions, but also non-military tasks

\footnotetext{
${ }^{11}$ It also has huge military-industrial power. So do Britain, Russia, and France.

${ }^{12}$ Morris Janowitz, The Professional Soldier (Glencoe, IL: Free Press, 1960), 8-12.
} 
such as disaster management." Finally, Moskos argued that the armed forces' prestige and "social status would relatively decline."13

In many respects, these predictions for modernization applied, both with regard to the old European nations' armed forces and those of the disintegrating Warsaw Pact. In the former nations, political and economic post-modernistic understandings and practices were developing fast; in the latter, there was and still remains much post-glasnost and post-perestroika confusion. Some nations of the EAPC group are attempting modernizing and post-modernizing simultaneously as they reform their militaries, while others had long ago postmodernized their militaries into inefficient, symbolic/non-effective, or dysfunctional institutions. It is not unfair to assert that some neutral nations' declared position is a luxury guaranteed by the military efforts of neighboring non-neutrals, who stand ready to fight for them. The antithesis, perhaps, of the "warrior" is not just the professional, but the "civilized soldier," a term increasingly used in politico-military parlance in liberal democracies with strong military forces..$^{14}$ But the professional soldier has sometimes to perform some very brutish, offensive, unpleasant, and "uncivilized" tasks, none more so than in intense combat. Hence the term "warrior" is retained.

The most bewildered warriors remain those of the post-communist European nations. Three British analysts - Andrew Forster, Timothy Edmunds, and Andrew Cottey - have gathered together research on the present position and likely development of professionalization programs in Central and SouthEastern European and Baltic states, as well as the Ukraine and Russia. Intriguingly, the writer on the Russian armed forces, Dale R. Herspring, bases his conclusions on what he describes as a program of "de-professionalizing." In making sense of all this analytical activity, as viewed from the outside (only one of seventeen was a professional military man), the authors have developed a useful definition and "typology" of armed forces, leading towards "ideal" types - ideal meaning according to researchers' models, not what is ultimately morally desirable. ${ }^{15}$ The programs inevitably look to the phasing out of conscription in many of the nations, a process that is at times seen as running counter to the variables of their geo-political defense and security positions. In this they are

${ }^{13}$ Charles Moskos, "Armed Forces after the Cold War: The Personnel Implications," in Seminar Proceedings of the British Military Studies Group - Centre for Defence Studies, King's College, University of London, 20 December 1990, 15.

${ }^{14}$ Patrick Mileham, "Building the Moral Component," in Military Ethics for the Expeditionary Era, eds. Patrick Mileham and Lee Willett (London: Royal Institute of International Affairs, 2001), 61.

${ }^{15}$ Anthony Forster, Timothy Edmunds, and Andrew Cottey, eds., The Challenge of Military Reform in Post Communist Europe, Building Professional Armed Forces (Basingstoke: Palgrave MacMillan, 2002). Ideal typology is presented by the authors on pp. 8-12: "Active engagement (power projection ideal type, territorial defence ideal type); Limited engagement (post-neutral ideal type, neutralist ideal type)." These are modified by variable factors and characteristics of "role, expertise, responsibility (chains of command and delegation) and promotion (career progression) typologies." 
like many Western European nations; indeed, much of the work of these authors has universal application.

In the view of Karl Haltiner, there has been a general three-phased trend in the region: the downsizing of armed forces (1990-95), a "NATO-led internationalization and professionalization phase" (1996-2001), and a wave of modularization and increasing flexibility since about 2000/1. He writes generally about the demilitarization of societies in some thirty European nations and, in peace support operations, a trend toward the "constabularization and internationalization" of armed forces. He also writes of the widening civil-military gap in some nations, and what he describes as a "re-militarization of the military."16 Much of this observation confirms what Janowitz and Moskos anticipated, but it is the remilitarization or further professionalization of the full-time cadre that needs further anticipatory analysis and subsequent confirmation.

What follows in this article is an attempt to view, as if from inside the military, the principles that can lead to an end-point for the smaller "well paid professional cadres" that should, may, or will prevail in many of the EAPC nations in perhaps twenty years' time. The following sections investigate in turn the variables within each of the three thematic defining components of "military effectiveness" and "fighting power" already referred to. Some objective, some subjective, but all qualitative, these identifiable variables lead tentatively towards a rigorous system of evaluation of the military profession, which in the foreseeable future should become universally acceptable.

\section{The Disciplines of Theory}

Whether military, academic, functional, or financial, any system of analysis requires objective disciplinary methods for evaluating theory and practice. In discovering theoretical conceptual and cognitive disciplines for armed forces in liberal democracies, it is necessary first to re-emphasize the need for civilian control over the military.

The monopoly over the use of force by government is a defining feature of liberal democracy. In theory, civilian ministers (and the civil servants answerable to them) should legally be given complete policy, managerial, and financial control over all uniformed officers, senior and subordinate, in the military hierarchy. How closely this theory is matched in the practice of enhancing security and defense needs is another matter. Clearer definition of the personal function and authority of civilians and military functionaries alike is required, but the routines, and above all the quality of relationships at all levels, will dictate whether or not civilian officials and military directors, commanders and managers, achieve the highest possible standards of internal efficiency and external effectiveness for their military institutions.

\footnotetext{
${ }^{16}$ Karl W. Haltiner, "From Centre to Periphery. The European Post Cold War Military Reforms and their Impacts on Civil Military Relations," forthcoming from the Centre for the Democratic Control of Armed Forces, Geneva.
} 
All persons concerned, from the minister of defense to the last corporal or private soldier, "hold office." In democracies, executive power is based on service to the nation. A definition of the "holding of an office ... [embodies] expectations of ... certain standards ... of the agent or office holder. The office is a trust in the legal sense of trusteeship." ${ }^{17}$ In ideal democracies, executive power is based ultimately on elected trusteeship. The electorate categorically denies absolute, permanent power to individuals. This does not mean that unelected, "permanent" professionals hold constitutional powers over elected representatives in any other respect than trusteeship in their professional capacity, defined or implicit. ${ }^{18}$ The professionalism of civil servants, as well as the quality of political leadership of ministers - one definition of leadership is the raising of expectations, as well as trust and proof of their fulfillment - is part of the formula.

Civil control over the military works well when each group of office holders - elected, or permanent, civilian or uniformed - are indeed experts, as Philip Everts requires them to be, and in whom the public places trust. The quality of the theory of the civil-military relationship is thus based on high degrees of trust, as promoted and maintained internally amongst trustees, and between these trustees and the public. Each category of official - political, ministerial, civil service, and military - has duties within this relationship. It is essential that ministers should not formulate rash or unreasonable policies, or give reckless commands, orders, or instructions, either in the routine administration and management of armed forces or on operations.

Military officers in truly professional armed forces do not have the right to refuse the call to comply with orders, but as a professional duty they have the right to use every means of persuasion (except political) to prevent the launch of reckless and ill-considered military actions and operations. While working within the constraints of domestic law, they also have to comply with international law. This is what Janowitz means by an "explicit political ethos." Well-conducted joint, routine, professional work, including risk-calculation, with respect to the expected end-state of military action, linked with legal, diplomatic, economic, and other considerations and actions should reduce or eliminate professional (or even traces of political) conflict between categories of professionals. All of these criteria having been met, trusted national armed forces can take their full place in alliance and international military coalition activities, where the same standards of trusteeship apply.

The second discipline of the military profession addresses the depth and breadth of military thought and doctrine. At the highest level of thinking, the tradition of objectivity is a defining characteristic of the profession, yet this mode of thought links it with other professions and the general population. The

\footnotetext{
${ }^{17}$ Andrew Dunsire, "The Concept of Trust," in Teaching Ethics, Volume 1. Government Ethics, ed. Rosalind Thomas (Cambridge: Centre for Business and Public Service Ethics, 1989), 336-37.

${ }^{18}$ The U.S. model of large numbers of "political" civil servants, brought in as the president's "administration," is copied by some nations, with or without checks and balances.
} 
resultant body of knowledge and wisdom, constantly reviewed and developed, should be codified in written form. But it must also be implicit in the collective wisdom and memory of the profession. Knowing when doctrines and practices are becoming outdated and reactionary is part of expert, professional judgment.

Military doctrine proper, like any professional doctrine, has the purpose of providing "first principles," both empirically derived and a priori, from which the profession and its supporting institutions and agencies can, literally, conduct research for new details, or sometimes new first principles. Publications of combat and operational doctrine, policy, and practice need to be written at various levels of theory and practice - grand strategic, strategic, operational, and tactical, in NATO terminology. A large number of supporting documents also need to be published to reflect the complexity and sophistication of a nation's armed forces, their duties, activities, and management.

Thus, quite distinct from the managerial infrastructure, which is part of force design, professional armed forces need to create strong links with external research institutions and maintain internal institutions which can study and develop the armed forces, as well as their links with other professions, occupations, and organizations. Some nations have military universities and specialist colleges. Many have staff colleges, where specialists join together to learn the art and science of generalist thinking, the wider application of force, and the various needs of security. Officer academies and training institutions for noncommissioned ranks and recruits likewise exist in all nations with any claim to modern, functional armed forces.

The third discipline of mature, professional armed forces is how they are conceived to interact with other institutions and agencies involved in providing national and international security. This should include the reciprocal quality of network relationships; other institutions, of course, also need to be highly professionalized for their relationships with the military to be efficient and effective for all parties. Typical national institutions are: intelligence agencies; civil police (unarmed or lightly armed police); gendarmerie (armed police); militia or national guard (volunteer); citizen army (conscript); volunteer, part-time armed forces, formed as military units; border guards; customs officials (including immigration control and revenue collection); and other emergency agencies.

These are distinguishable because, in most democratic nations, the term "professional" is normally applied to full-time armed forces as the ultimate embodiment of the monopoly of violence under government control. Every institution and agency should themselves have clearly-defined roles and routine tasks, with as tight parameters as are appropriate, reasonable, and workable. Some would need to be demilitarized, since they currently overlap and conflict with the duties of regular armed forces. If there are efficient, routine, and normal overlapping roles and tasks, they must also be defined. It can be argued that, if one or more of these institutions fail, particularly in times of national emergency, the professional armed forces can be tasked to do their work, as apolitical manpow- 
er of last resort so to speak, albeit with varying degrees of efficiency.

The fourth idealized and theoretical discipline of fully professionalized armed forces is the quality and quantity of resources allocated and the way they are configured. "Force design" is a structural and physical conception, subject to the close direction of policy makers - both civil and military - matching role and tasks with capability.

While the ability to guarantee total security from external aggression, or the ability to operate militarily far from their borders, is not claimed by many nations, some seem to accept wholly inadequate force capabilities even as full members of alliances for collective-defense: to them adheres the label "free riders." The claim of professional military status implies levels of high functionality, much closer to the total national defense end of the spectrum, than the minimum and symbolic.

In determining adequacy, one starts with constraints or opportunities of "polemity ... the ratio of the energy employed (directly or indirectly) in warfare or preparations for it, to the total amount of energy available to society." 19 This crudely equates to the amount of GDP set aside for defense, and security more generally. If an insufficient budget is available to man, equip, and support armed forces to meet foreseeable or unforeseeable emergencies, they are likely to fail; in the event, their capability will not match their tasks.

There is little space in this article to discuss force design in detail. Included under this rubric, however, should be policy direction, management, funding, and other resources providing for a sufficiency of combat units, supported directly by "combat support" and "combat service support" units and personnel (to use NATO terminology). Systems, both material and managerial, together with a large array of military processes and procedures, are included in force design, based on sustaining operations over distance and time. The energy employed in concert with the design, development, procurement, maintenance and logistical support of all materiel, including consumables, together with relationships with home and international defense industries, are also closely connected with the quality of defense output, and to use the obvious financial term, the return on military investment. Professional armed forces need professional infrastructures of sufficient comprehensiveness, sophistication, and flexibility to act quickly in emergencies and for as long as necessary.

The quality of relationships, doctrines, and force design are thus significant indicators of professionalism. Armed forces that obviously fail, through paucity of quality and resources, will be diminished professionally in their own standing, and externally amongst populations, both at home and abroad, and of course by any enemy they encounter operationally. This leads to the second group of disciplines.

${ }^{19}$ Stanislav Andreski, Military Organizations and Society (London: Routledge and Kegan Paul, 1954), 127-28. 


\section{The Disciplines of Practice}

The above disciplines of military effectiveness and fighting power should be evident in practical military application, resulting in proof of efficiency, or competence effectiveness.

The fifth discipline is that of technical expertise and use of technology. The techniques of fighting, from close quarter combat to the use of sophisticated high-tech weapons and equipment, constitute the practical, physical components of military power, subject to the policies, disciplines, and practices of force design already described. How efficiently the "technology" is used is based on military disciplines in the widest sense.

"Technical," meaning military specialist policies and practices are, of course, derived from doctrine, research, education, and training, and are passed on to new generations of servicemen and women, who in turn develop new policies and practices. In addition, the collective memory and wisdom of the armed forces needs to be fully engaged in order to perpetuate those skill sets useful in preparation for, and conduct of, military operations. Thus is "human capital" built up amongst military manpower over time.

Regular armed forces are unusual in one sense. They spend much time in training, preparation, and exercising their skills, both physical and mental, in only the partial expectation of having to apply them in real military situations. Ideally, most wise military professionals would live in the hope of not having to go to war, and not having to be involved in much danger or risk in operations other than war. If called upon to conduct hostilities, the natural and pragmatic desire is to "get the job done" quickly and effectively. Members of fully professional armed forces thus accept the policies, practices, preparations, and peacetime exercising of their skills, in the expectation that they are thereby reducing the danger levels of real operations and combat. The possession of well-trained armed forces increases the ability to deter an enemy attack and promote international security more generally.

The sixth discipline of professionalism is directly connected with ways and means. Armed forces, like any profession, need constantly to regenerate themselves. Professional armed forces are thus defined by the quality of their training and education. To continuously learn and improve individual skills, both practical and procedural, when working closely with others in teams (as the military routinely are required to do) is essential. Even for armed forces of modest size, this is a major effort of national polemity and resources. As military activities represent a very large-scale enterprise, unit, formation, joint, service, and combined (alliance) corporate training needs to be rigorous, realistic, and conducted continually.

For the career (as opposed to the short-service) personnel in armed forces, increasingly weight has been placed on education, taking personal understanding and skill much above the next level of promotion. Only one gen- 
eration ago in the British Army, it was entirely accepted that "training [was for] people only in the skills they need, as near as possible to the time they are going to need and use them." 20 There was also not much requirement for the "soldier/scholar"; there now is. Education is conducted for the improvement of the mind's capacity to understand what, how, and why things happen and why people act, or should act, in general, and in this case in particular military contexts. Education of military leaders for the higher direction of forces, requiring independence of thought, ability to analyze critically, and argue both orally and in writing, is now widely accepted in professional national armed forces as a necessity, if everyone is to do their job expertly, cope with the increasing complexities of operations and advancing technologies, and enable civilians to understand military activities. The proportion of officers and NCOs educated at higher education levels is a significant indicator of quality, although additionally all armed forces personnel of any rank need to be highly practical, able to think decisively and act quickly. Extending the military education fields has also required an increasing amount of defense- and security-related research and development, to keep military officers (both commissioned and non-commissioned) abreast of other professionals, and relate them with the civil population and other parts of the employment market.

The next discipline of practical significance is that of measuring military performance, in terms of interior efficiency and effectiveness in achieving tasks. Sophisticated systems have been adopted by some national armed forces, in line with other public sector organizations, based on meeting measurable standards and objectives within a certain financial budget. ${ }^{21}$ Statistical exercises in peacetime can be conducted to measure capability against roles and a wide range of tasks performed. The amount of individual recruiting, training, education for expertise, and qualification attainment can also be recorded and analyzed for trends that are maintained and improved (or show deterioration). Exercises and even operations of a limited scale can similarly be judged for quantity and quality of achievement. Major operations, conflicts, and wars conducted by armed forces tend to be measured not only objectively, but also in terms of political achievements as first-order consequences. Second- and thirdorder consequences are rather more difficult to assess. The chief aim of performance measuring is continuous improvement.

Professionals, by definition, take prime responsibility for improving and developing their own standards, and for modern liberal democracies, accountability and transparency of all the professions is a defining characteristic. The conceptual and physical components of military professionalism, how-

${ }^{20}$ Colonel R. H. W. Crawford, "Officer Training," correspondence in British Army Review 81 (1985): 73.

${ }^{21}$ There are many civil "benchmarking" schemes for commercial and public sector organizations in the West, e.g. the EU-sponsored ISO 9000 series of standards, the European Foundation for Quality Management Excellence Model, Investors in People, etc. 
ever, can be judged rather more easily than the moral or subjective attributes of the profession, which are our next topic for discussion.

\section{The Disciplines of Subjectivity}

The first of the intangible, subjective disciplines of military professionalism is the relationship of the armed forces with the civilian population as a whole - the "suppliers" of manpower and the "customers" of the service provided.

This relationship in individual nations is frequently measured and assessed, more or less scientifically, with volunteer enlistment figures, or the volume (percentage success) of the intake in countries where conscriptions still prevails. ${ }^{22}$ Haltiner's work and Philip Evert's recent book, Democracy and Military Force, illustrate the extent to which civil-military relations, and particularly civilian attitudes, have been surveyed and analyzed by some nations, sometimes almost in the belief that armed forces exist only to be the subject of social research. The standing of armed forces as bulwarks of democracy has been measured by two particular surveys. The European Values Group Surveys (Gallup), conducted in 1979 and 1989, ${ }^{23}$ and the National Pride Survey (Chicago) of $1998^{24}$ have measured populations' confidence in their armed forces over the years.

The relationship between the armed forces and the population from which they draw their recruits, including potential officers, depends on six chief variables, most of which are self-explanatory.

- How "close" or "isolated" the armed forces and their society are in spirit, attitude, and "visibility."

- Voluntary or conscripted service.

- Martial or militaristic style of internal relationships within the military.

- Demographics of military personnel, their qualifications, and promotion opportunities within the manpower "force design."

- The national/international labor market.

- Armed Forces' reputation.

All are interlinked and interdependent; one needs special comment.

In contrast with large conscript armies of varying and dubious efficiency, bolstered by aging reservists, the demography of already all-voluntary regular armed forces is not generally understood. There is an implication that, since current fully professionalized navies, armies, and air forces are action-based

\footnotetext{
${ }^{22}$ Haltiner, "From Centre to Periphery."

${ }^{23}$ Measuring the value placed on institutions of democratic states in Western Europe, such as parliaments, judiciary, police, press, education, armed forces, etc. Quoted in Daily Telegraph, 23 September 1991.

${ }^{24}$ Tom W. Smith and Lars Jarkko, National Pride: Cross-National Analysis, Report No.19, University of Chicago, National Opinion Research Center (May 1998). Willingness to defend the nation is an often-surveyed question.
} 
enterprises with offensive and not just defensive roles, they chiefly attract young persons at the beginning of their working-life. Quite apart from physical occupational risk, as people mature, the majority require more stability and/or opportunities to progress to more financially rewarding and intellectually challenging phases in their lives. To maintain vigorous armed forces, only a small number - probably less than one quarter - are likely to be retained by the armed forces for senior non-commissioned and middle ranking commissioned and senior officer cadres - the "career" armed forces. The turnover of the volunteer "short service" element is extremely high, but that is not to say that they need not be highly committed, trained, and professional during the period of their service.

The next characteristic of professional armed forces remains an open question. By definition, do fully professional armed forces need to be wholly "voluntary"? On the face of it, it appears that there is an intuitive movement towards this being a defining requirement in liberal democracies, but confused thinking continues. Most nations in Europe, including former members of the Warsaw Pact, are intent on eliminating conscription over time, with an expressed end-date. One cannot, however, say that the Israeli or Swiss citizen armies are less than professional in the context of their roles. Defending home territory is a different matter than the ideal types of armed forces designed for force projection.

In many respects, this indicator of quality is closely related to the armed forces' relationships with the civilian population, controlling authorities, and other agencies of national security. To answer the question, one has to search among the psycho-philosophical complexities of individual as well as group motivation and morale, but common sense indicates that one volunteer, motivated by choice, may be worth a number of pressed men, as the familiar expression has it. One has to ask, however, how willing is the volunteer? Certainly, according to the British military doctrine of 2000, there is the requirement for all members of the armed forces to accept the "legal right and duty to fight and if necessary, kill, according to their orders and an unlimited liability to give their lives in doing so. This is the unique nature of soldiering." ${ }^{25}$ This statement is deemed a "covenant," not a "contract." Perhaps that is why the expression "warrior" is retained, to reinforce the "war fighting ethos," 26 the "superior good" prevailing over otherwise intransigent evil in "power projection" armed forces. Nations that have written military "contracts," which do not include such statements, may have unprofessional (in the specialist sense) inhibitions guaranteed by human rights law. As a result, military duty may become weakened or meaningless.

\footnotetext{
${ }^{25}$ Army Doctrine Publication, Volume 5, Soldiering the Military Covenant, Ministry of Defence (Britain), Army code no 71642, February 2000, 1-1.

${ }^{26}$ War fighting ethos," in British Defence Doctrine, $2^{\text {nd }}$ ed. (London: Ministry of Defence, 2001, 3 4 to 3-5. "Superior public goods" are usually held to be health, education, and personal security.
} 
The question must be, is voluntary unlimited liability the most significant of all indicators of military professionalism? The answer is likely to be found in the argument that the majority of those who join the armed forces voluntarily in the first place are more likely to accept this unique liability, even if for only a brief period of their lives, than those who are coerced into joining. In different nations, different armed forces, and indeed different parts of an armed force, a variety of factors exist from the beginning of a person's service and before he or she takes part in any operations. In the event of active service, or once combat begins, who knows how oneself or others will behave and act? Most of the evidence of bravery or avoidance of danger (if observed) is ex post facto.

On balance, with all arguments considered, I believe that fully professional armed forces should be entirely voluntary by definition. All other professions I can think of are voluntary and fully disciplined groups of persons, in many senses of the adjective.

The tenth professional principle is military discipline itself. Traditionally understood, according to Max Weber, it means:

the consequently rationalized, schematically trained and accurate execution of received orders - without giving expression of personal criticism - and the constant inner submission to that objective. ${ }^{27}$

Traditional, un-modernized armed forces rely for their efficiency and effectiveness on varying degrees of coercive conditioning by authoritarian, militaristic means. Modernized armed forces could be said to promote rational, enlightened, more consensual means to inculcate discipline.

National military laws, written codes of conduct, and unwritten practices exist, more or less modernized to suit changing conditions, within a particular armed force and more or less in accord with the laws of the parent society. Disciplinary procedures taken against those who violate these norms are needed to show exemplary justice, punishment, and to reform the individual. For serious offenses, courts martial try individuals in a fashion similar (or not so similar) to the way in which national civilian courts try cases of criminal or civil law. This constitutes the lower purpose of military discipline. The higher purpose of such procedures is to uphold high standards of professionalism, promote successful military endeavor and high morale, as well as maintain public confidence.

A moot question arises: is self-discipline a higher, more voluntaristic, psycho-philosophical motivation than imposed discipline? In voluntary armed forces, self-discipline certainly is highly prized as a natural consequence of voluntarism. The question is, then, how necessary and to what extent is imposed discipline able to develop inner-directed self-discipline? The justification for

${ }^{27}$ Max Weber, Economy and Society (Berkeley: University of California Press, 1978), 866. 
induced discipline by authoritarian means (lightly applied for the intelligent, more strongly applied for the slow-witted) in the armed forces of liberal democracies has to do with setting the highest standards. Be a recruit ever so well motivated and keen to show self-discipline from the outset, he or she may not be aware of the required institutional professional standards. The intelligent commander or instructor will therefore quickly recognize high motivation and use appropriate methods to encourage the potentially self-disciplined, intelligent recruit or trained soldier. There should be no need to resort to highly militaristic methods which, as time progresses, for volunteer armed forces have an increasingly dysfunctional impact.

A seemingly permanent feature of military effectiveness is the dichotomy of the commander and the commanded. It forms the penultimate principle of professionalism. All armed forces continue to employ a wide range of rank distinctions amongst their members. They also maintain formal distinctions between commissioned officers, non-commissioned officers, and holders of subservient office - private soldiers or enlisted men. In their force designs, individual nations need to categorize the statuses of individuals and the internal demographic shape of their armed forces' personnel structure as part of normal manpower planning.

What can be stated about all members of the military hierarchy is that there are formal, professional relationships at many levels, which define the hierarchy and who can make what decisions - operational and in other contexts - and who has to obey them. Some of these formal relationships are well defined, highly developed, and entirely relevant; others may be accidental or archaic. Clarity about who can impose discipline and punish according to military law is the crucial division between commissioned (superordinate by legal instrument), warrant (subordinate qualified status), and non-commissioned ranks and those holding no rank or formal office at all.

While shades of militarism may still persist, much of the time in truly professional armed forces, informal, interpersonal relationships exist between persons working closely in teams together, to good effect. ${ }^{28} \mathrm{~A}$ "professional relationship" is a well-established and useful term, implying mutual respect. Some military cultures, conversely, may be too informal, rendering them less than effective. Workable, modern, professional relationships, meaning a mixture of formality and informality, are probably easier to achieve in voluntary armed forces. Conscripts tend to be deeply divided from cadre NCOs and career officers, and healthy informal relationships are unlikely to be formed as part of the military culture.

An indication of the high quality of professionalism within armed forces is therefore an understanding of the need for hierarchies and rank struc-

${ }^{28}$ See Charles Kirke's four socio-anthropological 'structures' in "A Model for the Analysis of Fighting Spirit in the British Army," in The British Army. Manpower and Society into the Twenty-First Century, ed. Hew Strachan (London: Frank Cass, 2000), 227-41. 
tures, the clarity of status, the quality of formal relationships and, equally important, the quality of informal relationships between real, live human beings working together in circumstances of difficulty or danger. An understanding of when one should act formally with a senior or subordinate person, or switch to informal means of communication and interpersonal action, often enables the whole military endeavor to work, organically as well as systematically, towards a greater likelihood of success.

Finally, there is a group of intangible factors that need to be brought together to promote and sustain professional, effective, and "usable" armed forces. ${ }^{29}$ They are institutional and personal leadership and a well-developed, natural corporate ethos, leading to high reputation and morale. These are noticeably lacking in most conscript forces. It has been found that, in civilian organizations, typically "up to 85 percent of a corporation's value is based on intangible assets," and if those assets are not effective, the company declines or collapses under external pressure. ${ }^{30}$ So what is the case in military organizations?

Numerous, mainly inconclusive works have been written, and many opinions expressed about leadership. Two significant factors spring to mind. Effective leaders are successful. They bring high quality to their own performance and that of those they lead, collectively and individually. Essentially, leading is an inspirational activity, which by definition is spiritual both in quality and performance. ${ }^{31}$ Leaders raise expectations amongst the led: consistently effective leaders faithfully fulfill or exceed expectations. Professional armed forces, as a qualitative indication of their standing, manifestly require to be commanded by officers (commissioned and non-commissioned) who are effective leaders, and amongst the best of their generation. Their duty is to motivate. Motivation is a variable factor, based on willingness and choice. Strong motivation, self-directed choice, and intelligent obedience are likely features of professional, volunteer armed forces.

The ethos of an institution is, again, an intangible, spiritual quality. In short, it can be described as ethical culture. "Ethics differ from morality in that conduct may be described as 'moral' when it is maintained or observed as fact, but becomes 'ethical' as it rises from fact to ideal." 32 Ideals, values, beliefs, and

\footnotetext{
${ }^{29}$ A clearly expressed requirement in the introduction to the publication of Britain's Strategic Defence Review, Modern Forces for the Modern World, 1998, 1. The contrast is with "Forces in being," that is, forces for deterrence and display only, not for "use."

${ }^{30}$ David Norton's Foreword to Brian Becker, Mark A. Huselid, and David Ulrich, The HR Scorecard. Linking People, Strategy, and Performance (Boston, MA: Harvard Business School Press, 2002), ix.

${ }^{31}$ See Patrick Mileham and Keith Spacie, Transforming Corporate Leadership (London: Financial Times/Pearson, 1996), 21-34.

${ }^{32}$ Rosamund Thomas, The British Philosophy of Administration (Cambridge: Centre for Business and Public Sector Ethics, 1989), 141. F. S. Northedge draws attention to the ideal, or ethos, and kratos, or reality, of human behavior in the real world less than ideal. See Northedge, The International Political System (London: Faber, 1976), 222.
} 
performance are all part of the ethos of armed forces. High standards - the ability to fulfilling professed claims - are an aspiration of all professional persons who take their calling seriously. "Ideal excellence" and "the 'genius' of an institution" are other, dictionary meanings of ethos. The study and promotion of standards of ethical behavior in the military context - above and beyond the legal requirements - is increasingly conducted at officer academics and practiced on operations. ${ }^{33}$ Integrity of armed forces, in many senses of the word, is of paramount importance.

Morale is dependent not only on internal factors, such as are listed in all the indicators of professional quality mentioned above, but significantly in terms of reputation amongst the civil population and other professions. Reputation, "that immortal part" of a person or institution, is of particular sensitivity in life-and-death occupations. ${ }^{34} \mathrm{~A}$ high reputation is dependent on high standards of internal leadership and morale, exemplified by faithful and effective performance.

All these factors are dynamic and variable. They are also fragile. Even modest failure can affect morale and reputation severely and undermine ethos. So the best guarantors and trustees of morale, ethos, and reputation are the leaders, personified by both military and civilian holders of office. The morale of armed forces is thus closely linked to standards of leadership and the collective confidence and commitment individual members feel, based on ideals and ethos. Low morale is the consequence of fear of failure, or actual failure. It is, moreover, dependent on numerous situational factors, personal relationships, and events. Some of these can be measured and an assessment made of their consequences for corporate morale, commitment, and performance. ${ }^{35}$ Finally, morale reflects the quality of the civil-military relationship explained above. Morale and confidence are synonymous.

\section{Conclusions - Universal Disciplines}

"The true soldier is the enemy of the beast in man, and none other," asserted Field Marshal Montgomery. ${ }^{36}$ In a modern liberal democracy, that person is the civilized warrior.

Nations and alliances get the armed forces they deserve, just as they do governments. Circumstances change, as do perceptions; if one is optimistic, then they change for the better. The perceptions of professionals and the public, based on retaining a firm connection with reality as it affects the objectives of

\footnotetext{
${ }^{33}$ The Joint Services Conference on Professional Ethics (JSCOPE) in the U.S., and the Royal Institute of International Affairs and United Services Institute's recent series of "military ethics" conferences, are evidence of research and debate.

${ }^{34}$ William Shakespeare, Othello, Act II, Scene iii, line 266.

${ }^{35}$ See Mileham, ed., “'Morale in Armed Forces' Conference Proceedings", RUSI Journal (April 2001): 46-53.

${ }^{36}$ Field Marshal Viscount Montgomery, History of Warfare (London: Collins, 1968), 567.
} 
professional practice, is crucial. Combat and operations other than war, including peace support, are the raisons d'etre of armed forces. Professional failure is therefore dangerous, and the full extent of the dangers is not necessarily apparent before the event. Military effectiveness in normal day-to-day work, and the realistic expectation of success in operation, has to be the culminating point of all trust, trusteeship, and professionalism, both within the profession of arms and among those who direct and support their nations' armed forces.

In summary, the forecasts of Janowitz and Moskos are increasingly being realized in Europe and the West, but the quality of armed forces has to be constantly scrutinized. Armed forces will have to remain ready, able, and willing to fight as warriors, conducting some unpleasant and uncivilized, offensive, brutish acts of violence, death, wounding in body and mind and destruction - if they are called on to do so. This is what they profess to do, beyond their mere functionality.

Military professionalism needs to be measured and judged according to a universal conception of military power against both actual preparedness and performance. The disciplines, principles, criteria, and standards guiding armed forces include the following:

- Objective control by civil authorities who are themselves professionally and democratically led.

- Well-conceived and fully developed doctrines, from which all military activity flows.

- Mature and responsible relationships with other national and international security and defense institutions and agencies.

- Fully comprehensive force design, allocated resources, and infrastructures.

- Appropriate technological and technical expertise developed to a high standard.

- Highly trained and well-educated military personnel.

- Objective quantitative and qualitative performance measurement systems and processes.

- Supportive and understanding reciprocal relationship with the civil population.

- Voluntary basis of military service, workable contracts and terms of service.

- Corporate ethos of discipline and self-discipline.

- Healthy internal relationships in the hierarchy of ranks, based on effective leadership.

- High ethical standing, morale, and reputation, based in performance.

The only appropriate conclusion to this article is to comment briefly on internal and external reflexivity. It will have struck the reader that all these indicators of professionalism are interconnected and interdependent, both directly and indi- 
rectly. Robust systems and procedures for internal and international evaluation are useful in themselves for quality monitoring and control. In time, the above disciplines, and others developed by policymakers, can become confidence building measures of considerable persuasiveness. A true profession requires explicit, codified standards. "Such standards are Universal ... capable of general application irrespective of time and space," we are reminded by Huntington. ${ }^{37}$ Such could be the universal contribution of the professions of arms in forming a widespread international Security and Defense Identity to ensure the greatest possible collective security.

${ }^{37}$ Huntington, The Soldier and the State, 8. 


\section{Bibliography}

Andreski, Stanislav. Military Organizations and Society. London: Routledge and Kegan Paul, 1954.

Codner, Michael. "The RUSI Martial Potency Index 2002." RUSI Journal 147, no. 6 (2002).

Everts, Philip. Democracy and Military Force. Basingstoke: Palgrave, 2002.

Forster, Anthony, Timothy Edmunds, and Andrew Cottey. The Challenge of Military Reform in Post Communist Europe, Building Professional Armed Forces . Basingstoke: Palgrave MacMillan, 2002.

Janowitz, Morris. The Professional Soldier. Glencoe, IL: Free Press, 1960, 1960.

Lasswell, Harold. The Analysis of Political Behaviour. London: Kegan Paul, 1947.

Mileham, Patrick, and Keith Spacie. Transforming Corporate Leadership. London: Financial, 1996.

Mileham, Patrick. "Building the Moral Component." In Military Ethics for the Expeditionary Era, eds. Patrick Mileham and Lee Willett. London: Royal Institute of International Affairs, 2001.

Weber, Max. Economy and Society. Berkeley: University of California Press, 1978.

Zubok, Vladislav M.. "Why did the Cold War End in 1989? Explanation of "The Turn"." In Reviewing the Cold War. Approaches, Interpretation, Theory. London: Frank Cass, 2001. 